\title{
NEW PHASES OF UNFAIR COMPETITION AND MEASURES FOR ITS SUPPRESSION- NATIONAL AND INTERNATIONAL
}

\author{
Whliam Notz \\ Washington, D. C.
}

The world war has had a most wholesome effect upon commercial legislation in all parts of the world. It has focussed the eyes of statesmen, business men, and observant people generally upon the importance of fair play in commerce and trade. It has aroused the public conscience to the evil excrescences of modern business and has put people on their guard against the devious unfair methods of competition practiced in their midst. More than that, for the first time in the history of modern commerce earnest and practical efforts are being made to improve and elevate the rules and standards that govern world trade. The movement is national as well as international in its scope. What are its main underlying causes?

Rapid expansion of business enterprise, and the need felt by enlightened and progressive nations generally to safeguard their commercial life against the evils which so frequently accompany sharp trade rivalry, may account to a large extent for the growing attention given by foreign parliaments to this kind of commercial legislation. Apparently the apprehension of keener competitive conditions after the war, and the clamor on the part of domestic business interests for effective protection at home against possible unfair competition by foreign rivals, have also hastened legislative action. A third explanation is found in the world-wide efforts to check the power of private monopolistic enterprise by cutting off the roots which so frequently nourish and sustain monopoly.

This latter consideration was responsible primarily for the enactment of anti-unfair competition clauses in connection with recent anti-trust laws, and for the creation of special commissions or boards empowered to enforce them. The Federal Trade Commission Act and the Clayton Act in this country in 1914 became the forerunners of similar legislation in several foreign countries, notably Canada. The Canadian parliament on July 7, I9I9, passed two laws, the Combines and Fair Prices Act and the Board of Commerce Act, which in part follow very closely the wording of our own Federal Trade Commission Act. Among other duties, the Canadian Board of Commerce is empowered to restrain and prohibit the formation and the activities of combines which prevent or lessen competition in production, manufacture, purchase, barter, sale, transportation, insurance, or supply. The Board 
also has the power to take action leading to the revocation of patents used to prevent or unduly lessen competition.

Recent legislation by the parliament of New Zealand follows still more closely the system established by the Congress of the United States in the Federal Trade Commission Act. Under the Board of Trade Act, rgrg, the New Zealand Board of Trade is empowered to hold judicial inquiries in matters relating to unfair competition. Under section 26 of the act the Governor-General in Council is authorized to issue regulations on the recommendations of the Board of Trade

"for the prevention or suppression of methods of competition, trading, or business which are considered to be unfair or prejudicial to the industries of New Zealand or to the public welfare."

Offenses against such regulations are punishable by fine or imprisonment.

As far as the countries of Europe are concerned the most pronounced interest in matters relating to unfair competition has manifested itself in the Scandinavian countries. The phenomenal expansion of their commerce during the world war and the fact that in these countries a large part of the business between citizens of belligerent and nonbelligerent countries was transacted, probably made the need for a reform of their commercial legislation felt more acutely than might otherwise have been the case.

In Denmark, a new law against unfair competition became effective on October Ist, 1918. ${ }^{1}$ Its salient features relate to false marking of wrappers; labels; advertisements as to place and mranner of production, prices, and composition; reducing stock of goods or closingout sales; auctions; fraudulent use of firm names; defamatory or incorrect statements to entice competitor's customers; and betrayal of business secrets. Two novel provisions prohibit respectively the giving of premiums and selling below a fixed resale price. The latter provision prohibits the sale of goods marked by a producer or wholesaler with a fixed resale price below such fixed resale price, provided the fixed resale price does not allow a profit in excess of 25 per cent of the purchase price.

In Sweden a special committee appointed by the king was directed in I9I 3 to study the question of unfair competition. The committee submitted an elaborate report in 1915, which also contained a draft for a new law. ${ }^{2}$ Two sections of this bill, relating respectively to the divulging of trade secrets and to bribery, were passed on July 29th, I9I9, as a separate law. ${ }^{3}$ On June 22d, 1920, a new committee was appointed by the king. It is to submit to parliament at its next session a new bill, based on the report of the original committee.

In Norway a like situation exists. In I9I4 a special committee was

\footnotetext{
${ }^{2}$ Lov om Bestemmelser mod uretmaessig Konkurrence og Varebetegnelse (I9I8) Nr. 168.

2Förslag til lag mot illojal konkurrens.

'Lag med vissa bestämmelser mot illojal konkurrens. (19rg) Nr. 446.
} 
directed by the Storting to prepare a draft for a law against unfair competition. The committee submitted a report on June 3oth, Igrg. The billt which was drafted by the committee follows in general the same lines as the Swedish bill and the Danish law mentioned above. A notable difference, however, consists in the general clause (sec. I) of the Norwegian bill, following the German law against unfair competition of June 7 th, 1909, which also contains a general clause (sec. I).

Great Britain has been slow in following the lead of other countries in legislation and judicature dealing with unfair competition generally. Prosecution is brought chiefly under provisions of the trade-mark, anti-bribery, and similar special laws. The most noticeable progress has been made in the war against bribery and corruption, both in commercial and social life.

The Prevention of Corruption Act, I9I6, is the latest addition to the statutes dealing with corrupt practices. It amends the Public Bodies Corrupt Practices Act, I889, and the Prevention of Corruption Act, I906, and provides for more severe penalties for offences in connection with government contracts, or contracts or subcontracts with any public body. Penal servitude from three to seven years may be inflicted in addition to imprisonment under the Acts of 1889 and rgo6.

For the period from I9I4 to I9I9 inclusive a total of 63 convictions upon indictment were had under the three anti-corruption acts. For the same period there was a total of II6 summary convictions. ${ }^{5}$ The majority of cases involve offering, giving and accepting bribes to or by public officials, chiefly police and military officers.

Much of the success of the whole movement in England for the suppression of commercial bribery is due to the very active work of the Bribery and Secret Commissions Prevention League and to the untiring efforts of its secretary, Mr. R. M. Leonard.

In I9I8 a law for the prevention of corruption was enacted by the Union of South Africa, known as the Prevention of Corruption Act, 1918.

Under the common law, action by the English courts has not been in line with that of other countries. ${ }^{\circ}$ However, certain phases of unfair competition are dealt with in recent reports by special committees of the Board of Trade.

On the subject of resale price maintenance a sub-committee appointed by the Standing Committee on Trusts operating under the British Profiteering Act, I919, issued a report on March 30th, 1920.7

\footnotetext{
- Utíast til lov mot utilborlig konkurranse.

- Albert Crew, The Law Relating to Secret Commissions and Bribes, Civil and Criminal (2d ed. 1920) 178-190.

- Report of Committee on Trusts (London, I9r9) 33.

'Findings and Decisions of a Committee Appointed to Inquire into thePrinciple of Fixed Retail Prices (1920) Cd. 662.
} 
The Committee's view was that the system of fixing retail prices, as between manufacturer, wholesaler, retailer and public, is to the advantage of the latter. The reasons advanced by the committee in favor of resale price maintenance are as follows: I) In times of scarcity it does in fact check the undue inflation of prices; 2) in times of plenty it tends to ensure to all classes, including labor employed in manufacture and distribution, a fair rate of remuneration for the services respectively performed by them; and 3 ) in all conditions it tends to prevent speculative dealing by the middleman, who is prevented from taking undue advantage of violent market fluctuations and allocating to himself what properly belongs either (a) to the consumer, or (b) to the trader or manufacturer. These remarks are, however, subject to the overriding consideration that it is necessary that the price charged by the original producer or manufacturer shall be a fair and reasonable one, and not one which yields him an unreasonable profit or allows him to exploit for his own advantage the various conditions of the market either in raw materials, labor, or other factors of production.

In connection with the methods adopted for forcing upon the retailer the observance of the minimum price fixed, the Committee states that in almost all cases a clause is attached to the invoice making it a condition of the sale that the articles shall not be sold below the fixed price. Such a clause, the Committee states, is legally enforceable, and has in some cases been enforced.

Some far-reaching suggestions are contained in the report of the Merchandise Marks Committee, appointed by the Board of Trade, which was issued on June $23 \mathrm{~d}$, $1920 .^{8}$ As regards indications of origin on goods the committee recommended that the Board of Trade should have power to issue orders requiring that imported goods which are deliberate imitations of British goods, bear an indication of origin.

Under the Merchandise Marks Act, I89I, certain practices of false or misleading marking are not covered, for example, oral mis-descriptions, mis-descriptions in advertisements and catalogues, and false indications given by trading titles (e. g., the use of such a term as "Irish linen" in the title of a firm which does not deal mainly or exclusively in that commodity). To remedy this situation the Committee recommended that the existing act should be amended to include in the broadest possible manner all indications, descriptions or statements, oral, documentary, or other, whether physically attached to goods or not, including statements in advertisements or catalogues and false indications given by trade names or titles of firms or companies, which are reasonably calculated to lead a purchaser to a false belief as to the origin of the goods.

Believing that more active steps are necessary for the detection of

(1920) Cd. 760. 
offences against the act, the Committee recommended that local authorities should be authorized to act for the detection of offences in their own area, and also to prosecute and to charge the expenses to the taxes.

The Committee calls attention to the practice of false lapping or folding of piece goods, in laps of less than a yard, and the false reeling of yarn, whereby purchasers are deceived and unscrupulous traders gain an unfair advantage over honest traders. Legislation regulating the folding of piece goods is recommended and an international agreement on similar lines is deemed desirable by the Committee.

International action through the League of Nations or the Permanent Court of International Justice is also recommended in cases where a country fails to carry out its obligations under a convention and where representations to the foreign government prove ineffectual.

Finally, international protection is advocated in case of names of towns, such as Sheffield and Redditch, which are specially connected with particular industries.

An interesting change in the jurisprudence relating to unfair competition is to be recorded in the Netherlands. Effective prosecution was rendered nugatory until recently by the narrow interpretation given by the Supreme Court (Hooge Raad) to Article I40r of the Dutch Civil Code. This article provides that

"every unlawful act by which another person sustains injury obliges him by whose fault the injury has been caused, to compensate for the same."

For many years the Supreme Court took the ground that only such an act was unlawful under Article I40r as represented an encroachment on the legal right of another or as conflicted with the legal duty of the actor. Under this policy of the Supreme Court it was impossible to proceed effectually in the courts against unfair competition, except in the cases where the unfair act constituted a violation of a clear legal right, e. g., copyright, trade-mark, etc.

It is chiefly due to the efforts of the well-known Dutch jurist, Molengraaff, that a more liberal interpretation has finally gained favor and that an amendment of the existing law has been submitted to the Dutch parliament by the government (the so-called "Aalberse amendment"). It is significant that the Hooge Raad has already anticipated the proposed change in a leading decision of January $3 \mathrm{I}$, $1919 .{ }^{2}$ In that decision the court held as follows: Under the term 'unlawful act' is to be understood an act or an omission which is a violation either of the right of another or of the legal duty (Rechtspficht) of the person who commits the act, or which is contrary to good morals or to the care which in social intercourse is proper, relative to the personality or the property of another.

In line with this changed policy of the Supreme Court, a number of

\footnotetext{
'Weekblad van het Recht, t0365.
} 
cases of unfair competition have been successfully prosecuted during the past year, where under the old policy probably no remedial results would have been obtained.

In comparison with the noteworthy progress in recent foreign legislation against unfair competition, noted above, the court decisions, generally speaking, have followed along the customary channels of pre-war days. A survey of published decisions shows that the courts have not always kept pace with the numerous and rapid economic changes incident to the war. Trade journals and the foreign press generally report an ever-increasing flow of objectionable trade practices. Complaints on the part of business men and of the public are numerous as to the cumbersome machinery of the courts in the suppression of corruption, bribery, betrayal of business secrets, false and deceptive marking of goods, and many other even more modern schemes of injuring a competitor.

On the other hand, much credit is due to those prosecuting authorities and courts which have not permitted the rules of fair play in commerce and trade to fall into desuetude, but have vigorously enforced the standards of good business morals. A selected number of cases is here given which involve interesting new developments in the field of unfair competition.

Among the methods of competition which the Federal Trade Commission has condemned thus far are the following: $:^{\text {as }}$

Misbranding of fabrics and other commodities respecting the materials or ingredients of which they are composed, their quality, origin, or source.

Adulteration of commodities, misrepresenting them as pure or selling them under such names and circumstances that the purchaser would be misled into believing them to be pure.

Bribery of buyers or other employees of customers and prospective customers to secure new customers or induce continuation of patronage.

The payment of bonuses by manufacturers to salesmen of jobbers and retailers to procure their special services in selling their goods; and making unduly large contributions of money to associations of customers.

Procuring the business or trade secrets of competitors by espionage, by bribing their employees, or by similar means.

Procuring breach of competitors' contracts for the sale of products by misrepresentation or by other means.

Inducing employees of competitors to violate their contracts or enticing away employees of competitors in such numbers or under such circumstances as to hamper or embarrass them in business.

2n Annual Report of the Federal Trade Commission for the fiscal year ended June 30,1920 , p. 56-57. 
Making false or disparaging statements respecting competitors' products, their business, financial credit, etc.

The use of false or misleading advertisements.

Making vague and indefinite threats of patent infringement suits against the trade generally, the threats being couched in such general language as not to convey a clear idea of the rights alleged to be infringed, but nevertheless causing uneasiness and fear in the trade.

Widespread threats to the trade of suits for patent infringement arising from the sale of alleged infringing products of competitors, such threats not being made in good faith but for the purpose of intimidating the trade.

False claims to patents or misrepresenting the scope of patents.

Intimidation for the purpose of accomplishing enforced dealing by falsely charging disloyalty to the Government.

Tampering with and misadjusting the machines sold by competitors for the purpose of discrediting them with purchaser.

Trade boycotts or combinations of traders to prevent certain wholesale or retail dealers or certain classes of such dealers from procuring goods.

Passing off of products or business of one manufacturer for those of another by imitation of product, dress of goods, or by simulation of advertising or of corporate or trade names.

Unauthorized appropriation of the results of a competitor's ingenuity, labor and expense, thereby avoiding costs otherwise necessarily involved in production.

Preventing competitors from procuring advertising space in newspapers or periodicals by misrepresenting their standing or other misrepresentation calculated to prejudice advertising mediums against them.

Misrepresentation in the sale of stock of corporations.

Selling rebuilt machines of various descriptions, rebuilt automobile tires, and old motion-picture films slightly changed and renamed as and for new products.

Harassing competitors by fake requests for estimates on bills of goods, for catalogues, etc.

Giving away of goods in large quantities to hamper and embarrass small competitors; and selling goods at cost to accomplish the same purpose.

Sales of goods at cost, coupled with statements misleading the public into the belief that they are sold at a profit.

Bidding up the prices of raw materials to a point where the business is unprofitable for the purpose of driving out financially weaker competitors.

Loaning, selling at cost, or leasing for a nominal consideration pump and tank outfits to dealers on condition that they be used only for the distribution of the product of the particular manufacturer. Loans or leases of other equipment under similar conditions. 
The use by monopolistic concerns of concealed subsidiaries for carrying on their business, such concerns being held out as not connected with the controlling company.

Intentional appropriation or converting to one's own use of raw materials of competitors by diverting shipments.

Giving and offering to give premiums of unequal value, the particular premiums received to be determined by lot or chance, thus in effect setting up a lottery.

Any and all schemes for compelling wholesalers and retailers to maintain resale prices on products fixed by the manufacturer.

Combinations of competitors to enhance prices, maintain prices, bring about substantial uniformity in prices, or to divide territory or business.

In connection with the enormous expansion of the moving-picture business various kinds of unfair competitive practices have developed. An examination of recent decisions in foreign countries shows some novel cases in this comparatively new sphere of business.

The Oberlandesgericht at Karlsruhe, ${ }^{10}$ in a decision of July 3, I9I7, held that it was repugnant to good morals in business competition for one party to take advantage of the efforts of another by utilizing his advertising. Suit had been brought by the owner of a moving-picture theatre who had inserted coupons in his newspaper advertisements which when clipped and presented at his theatre entitled the bearer to a reduced entrance fee. Similar coupons were printed on the back of street car-fare receipts. The defendant, owner of a rival theatre, had announced in the newspapers that coupons for admission to his theatre and also coupons for admission to other theatres, when presented at the entrance to his theatre, would entitle the bearer to a reduced admission. The defendant acted in accordance with his promise. In issuing an order to cease and desist, the court held the methods practiced by the defendant incompatible with business integrity and decency.

Misleading offers and deceptive advertisements were resorted to frequently during the war in connection with schemes calculated to give the impression that the seller was selling his goods at a very small margin of profit. In a decision of the German Reichsgericht ${ }^{11}$ of December I7th, I9I5, it was held that an advertisement of a sale reading "Sale at cost price plus ten per cent" came under section 4 of the Unfair Competition Law, which prohibits untrue statements calculated to create the impression of an especially favorable offer. It was shown that the defendant included all general and overhead expenses in his so-called "cost price", while the public understood the advertisement to mean that the defendant had added to his net purchase price only the so-called "special expenses" and ten per cent. The advertisement, according to the court, led the public to believe

${ }^{10}$ (I9I8) MARKENSChUTZ UND WETTBEWERB, I36.

11 (1916) id. 206. 
that the defendant charged a gross profit of ten per cent, while in reality the ten per cent was net profit.

A somewhat similar case was decided in the Oberlandesgericht $\mathrm{Hamm}^{12}$ on October I9, I9I7. The defendant, a jeweler, announced in advertisements that he offered un-anticipated advantages to the public in connection with the sale of his goods and a discount of twenty per cent to his customers. In the opinion of the court the advertisement contained incorrect statements. The announcement of twenty per cent discount was meaningless, if the prices were fixed at pleasure and the specified discount was deducted therefrom. The announcement must have given the impression to readers that the defendant had marked all his goods with a fixed price and that, unlike other jewelers, he granted the high discount on such established prices. The announcement of "un-anticipated advantages" constituted not merely puffing advertising but led one to believe that the dufendant had made his prices considerably lower than was customary in similar shops.

The pronounced nationalistic tendency, which is making itself felt more and more in the political and economic policies of nearly all nations at the present time, reflects itself also in the sphere of unfair competition. Before the war there was a noticeable tendency in the court decisions of most countries to regard various designations, which originally were considered distinctive and special names, as generic or conventional. Many regional appellations, names of origin, hall marks, such as Port, Madeira, Pilsen, Camembert, Solingen, Sheffield, etc., received little or no protection by the courts. The lax use of such terms was spreading rapidly, and furnished a ready means for much confusion and deliberate deception.

The war has brought on a strong and healthful reaction. In addition to the instances mentioned above, of a return to a more strict and limited usage of such appellations, mention might be made of the French law of May 6th, I919, relating to the protection of names of origin, particularly Bordeaux and Champagne. An epochal decision of the German Patent Office of January 13, I9I4, also merits attention. It rejects the practice of linking up two designations of provenance (Elberfeld-Pilsener; Radeburger-Pilsener) and contending that one of the designations loses its character of provenance and becomes a designation of quality. The decision held that by means of such a double designation the provenance of the goods is not indicated in such a way as to leave no room for misunderstanding. It also declares unlawful every use of a geographic designation which does not correspond to the actual place of origin.

In the foregoing we have confined ourselves mainly to the national aspects of recent foreign laws and decisions dealing with unfair competition. Something remains to be said from an international point of view.

\footnotetext{
${ }^{22}$ (1918) id. 172.
} 
Prior to the outbreak of the world war the movement for international action for the suppression of unfair competition was making rapid headway. As late as the summer of I9I4, the International Congress of Chambers of Commerce, which met at Paris, had this subject under consideration. During the war and since increasing importance has been attached to the whole subject.

At the various economic conferences of the Allies during the war and at the peace conference, articles of agreement covering unfair competition were adopted. Articles 274 and 275 of the Peace Treaty of Versailles impose upon Germany the obligation to protect the trade of the Allies against unfair competition, and in particular, to suppress the use of false markings and indications of origin, and on condition of reciprocity, to respect the laws and judicial decisions of allied and associated states in respect to regional appellations of wines and spirits. The provision relating to regional appellations of wines and spirits is said to have been embodied in the treaty to meet the wishes of the French Syndicat des Viticulteurs des Clarentes, who for many years have protested against the use of the terms "cognac" and "champagne" as applied to foreign liquors sold under those names.

Article 274 provides as follows:

Germany undertakes to adopt all the necessary legislative and administrative measures to protect goods, the produce or manufacture of any one of the Allied and Associated Powers from all forms of unfair competition in commercial transactions.

The purpose of this article is not quite clear, for the German law against unfair competition of June 7 th, I909, already contains a provision (sec. 28) for the protection of rights of foreigners. In a number of cases brought under that section foreigners were successful in having their rights protected by the German courts. One of the most important decisions rendered under Section 28 was made by the Oberlandesgericht of Hamburg on May 20, I9I4, and upheld by the Reichsgericht $^{13}$ on June $4^{\text {th }}$, I920. French sardine packers brought suit against a group of Norwegian-English packers who sold Norwegian sprats in the German market under the name of sardines. The Hamburg court found in favor of the French concern. A similar suit, brought at the same time in an English court, was dismissed. Practically, the only net result of Article 274 lies in the fact that the number of states will be slightly increased whose citizens will be protected against unfair methods of competition.

Article 275 provides as follows:

Germany undertakes on condition that reciprocity is accorded in these matters to respect any law, or any administrative or judicial decision given in conformity with such law, in force in any Allied or Associated State and duly communicated to her by the proper authorities, defining or regulating the right to any regional appellation in respect of wines or spirits produced in the State to which the region

\footnotetext{
${ }^{13}$ Zivilsenat 2, II. $316 / 14$
} 
belongs, or the conditions under which the use of any such appellation may be permitted; and the importation, exportation, manufacture, distribution, sale or offering for sale of products or articles bearing regional appellations inconsistent with such law or order shall be prohibited by the German Government and repressed by the measures prescribed in the preceding Article.

The provisions of the foregoing Article are supposed to settle the longstanding feud between French and German producers of cognac and wines. On the one hand the designation "cognac" and the regional appellation for French wines are to be protected in the future, while on the other hand similar protection is to be accorded to the Rhine and Mosel wines against misuse and misappropriation of designations of provenance.

At the Second Pan-American Financial Congress held at Washington, D. C., in February I920, the subject of coöperation among the republics comprising the Congress for suppression of unfair competition was discussed. A plan for joint action was outlined by Commissioner Huston Thompson of the Federal Trade Commission, and the Congress subsequently adopted a resolution to make the study of the question a part of its program of work. Similar action was taken at the convention of the International Chamber of Commerce, held at Paris from June 23 to 30 , r920. The following resolution was adopted on the subject of unfair competition:

"Resolved, that the International Chamber of Commerce express the wish to see, among the first acts of the International Chamber, the creation of an appropriate body attached to each national bureau and to be under the direction of an organization of a similar nature attached to the general headquarters; that the duties of said bodies shall be to study, from a legal point of view, all questions relating to unfair competition, industrial property, trade marks, names of origin and misleading indications, and to prepare the reports to be submitted to the general meetings, which reports shall be printed and transmitted to delegates 60 days prior to each general meeting."

In the recent report of the British Merchandise Marks Committee, mentioned above, the subject of more effective international action for the protection of industrial property is discussed at considerable length and a number of recommendations made with that end in view.

To all appearances, therefore, the view seems to be gaining ground here and abroad that greater uniformity in laws against unfair competition and more harmonious coöperation in enforcing them can be best accomplished by concerted action on the part of the leading commercial nations of the world. 